\title{
Antibiyotik Olarak Kullanılan Sultamisilin, Sefdinir, Vankomisin Hidroklorür ve Kolistimetat Sodyum Etken Maddelerinin İnsan Serum Paraoksonaz-I Enzim Aktivitesi Üzerine in vitro Etkilerinin İncelenmesi
}

\author{
Merve Berivan ÖZÇELIK, Serhat YILDIRIM, Esra DİLEK*D
}

Erzincan Binali Yıldırım Üniversitesi, Eczacılık Fakültesi, Temel Eczacılık Bilimleri Bölümü, Biyokimya Anabilim Dalı

Geliş / Received: 05/10/2018, Kabul / Accepted: 07/01/2019

\section{Öz}

Paraoksonaz (PON1; E.C.3.1.8.1), karaciğerde sentezlenir ve spesifik substratı olan paraoksonu hidroliz eder. Yüksek yoğunluklu lipoprotein (HDL)'ne bağlı arilesterazlar grubundan bir enzimdir. Bu çalışmanın amacı, sıklıkla kullanılan antibiyotik ilaçların sultamisilin, sefdinir, vankomisin hidroklorür ve kolistimetat sodyum etken maddelerinin insan serumunda bulunan PON1 enzim aktivitesi üzerine in vitro etkilerini araștırmaktır. İnsan serumundan PON1 enzimi amonyum sülfat çöktürmesi (\%60-80 aralığında), iyon değişim kromatografisi ve jel filtrasyon kromatografisi teknikleri kullanılarak \%44,6 verimle yaklaşık 320,7 kat saflaştırıldı. Etken maddelerin inhibisyon etkilerini incelemek üzere enzimin 412 nm'deki paraoksonaz aktivitesine bakıldı. Substrat olarak paraokson kullanıldı. PON1 enzimi için sultamisilin ve vankomisin hidroklorür yarışmasız inhibisyon gösterirken, sefdinir yarı yarışmalı inhibisyon, kolistimetat sodyum ise yarışmalı inhibisyon etkisi gösterdi. Ki değerleri ise sultamisilin için $38.3 \mathrm{mM}$; vankomisin hidroklorür için $5.08 \mathrm{mM}$; sefdinir için 0.86 $\mathrm{mM}$ ve kolistimetat sodyum için $17.01 \mu \mathrm{M}$ olarak hesaplandı. Bu sonuçlara göre enzim aktivitesi üzerine etki gösteren ilaç etken maddelerinin içinde, enzim aktivitesini düşük konsantrasyonda $\% 50$ azaltması ile PON1 enzimi üzerinde de en kuvvetli inhibitör kolistimetat sodyum ( $\mathrm{IC}_{50}$ : $\left.13.59 \mu \mathrm{M}\right)$ olarak tespit edildi.

Anahtar Kelimeler: Paraoksonaz1, Sultamisilin, Sefdinir, Vankomisin Hidroklorür, Kolistimetat sodyum

\section{Investigation of the In vitro Effects of Sultamycillin, Cefdinir, Vancomycin Hydrochloride and Colistimethate Sodium Agents Used as Antibiotics on Enzyme Activity of Human Serum Paraoxonase-I}

\begin{abstract}
Abctract
Paraoxonase (PON1; E.C.3.1.8.1) is synthesized in the liver and hydrolyzes its specific substrate, paraoxone. It is an enzyme from the group of A-esterases bound to high density lipoprotein (HDL). The aim of this study was to investigate the in vitro effects of sultamicillin, cefdinir, vancomycin hydrochloride and colistimethate sodium active substances on the PON1 enzyme activity in human serum. The PON1 enzyme from the human serum was purified using ammonium sulfate precipitation (in the range of 60-80\%), ion exchange chromatography, and gel filtration chromatography techniques approximately 320,7 fold with $44,6 \%$ yield. The paraoxonase activity of the enzyme at $412 \mathrm{~nm}$ was investigated to investigate the inhibition effects of the active substances. Paraoxone was used as the substrate. Sultamycillin and vancomycin hydrochloride showed noncompetetive inhibition for the PON1 enzyme, whereas cefdinir showed a uncompetitive inhibition and colistimethate sodium showed a competitive inhibition effect. Ki values are determined for sultamycillin as $38.3 \mathrm{mM}$; for vancomycin hydrochloride as $5.08 \mathrm{mM}$; for cefdinir as $0.86 \mathrm{mM}$; and for colistimethate sodium as $17.01 \mu \mathrm{M}$. According to the results, it was determined that the most effective inhibitor colistimethate sodium ( $\mathrm{IC}_{50}: 13.59 \mu \mathrm{M}$ ) was found on the PON1 enzyme with 50\% reduction in activity at very low concentration.
\end{abstract}

Keywords: Paraoxonase1, sultamycillin, cefdinir, vancomycin hydrochloride, colistimethate sodium

\section{Giriş}

Tanımı yapılmış enzimlerin in vivo ve in vitro aktivitelerini azaltan veya tam anlamiyla yok olmasina sebep olan maddelere inhibitör denir. İnhibitörlerin sebep olduğu bu olaya ise inhibisyon ad1 verilir. Genel olarak inhibitörleri küçük moleküllü bileşikler veya iyonlardır. Enzimlerin inhibisyona uğraması biyolojik sistemlerde önemli kontrol 
mekanizmalarından en önemlilerinden birini oluşturmaktadır. Çoğu kimyasal madde, ilaç ve zehirli bileşikler de etkilerini bu mekanizma ile gerçekleştirirler (Dilek, 2012).Paraoksonaz (PON: E.C.3.1.8.1), karaciğerde sentezlenir ve spesifik substratı olan paraoksonu hidroliz eder. Yüksek yoğunluklu lipoprotein (HDL)'ne bağlı arilesterazlar grubundan bir enzimdir. LDL'nin oksidasyona uğraması aterosklerozun meydana gelmesinin başlangıç evresi olması, antioksidan özelliğe sahip olan enzimin ne kadar önemli olduğu bu sayede açığa çıkmaktadır (Durrington et al., 2001; Ng et al., 2005). Enzim, paraokson, metil paraokson ve klormetil paraokson'a karş1 yüksek derecede afinite gösterdiğinden ve ayrıca aktivitesinin ölçümünde ilk olarak paraokson substratı kullanıldığından PON adını almıştır (Mackness et al., 1998). PON, aktivitesi ve kararlığı için $\mathrm{Ca}^{2+}$ iyonuna bağımlı, 43-45 kDa molekül ağırlığına sahip bir enzimdir. (Canales and Sanchez-Muniz, 2003; Blatter et al., 1993). İzoelektrik noktas1 5,1'dir. 354 amino asit içeren serum PON1 enziminin amino asit bileşimi yüksek oranda lösin amino asidi içerir (Gan et al., 1991). Amino asit dizilişinde 3 sistein kalıntısından 284'deki serbest iken 42 . ve 353. sistein kalıntıları arasında tek disülfit bağ 1 oluşmuştur. İnsan serum PON enzimi, paratiyon'un metabolik ürünü olan ve organizmaya zararlı bir pestisit olan paraoksondaki O-P arasındaki ester bağını hidroliz eden bir esteraz enzimidir (Aviram et al., 1998). PON enzimi, paratiyon'un oksidatif modifikasyonu ile metabolizmada oluşan paraoksonu hidroliz ederek paraoksona oranla göreceli olarak daha az zararlı olan p-nitrofenol ile dietil fosfat bileşiklerini oluşturmaktadır (Mackness et al., 1998; Lee et al., 2001)PON enzimi HDL'ye bağlı antioksidan bir enzimdir ve LDL ile HDL'yi lipit peroksidasyonundan korur. Aynı zamanda HDL'nin başlıca antiaterosklerotik (damar sertleşmesini önleyici) parçası olduğu düşünülmektedir. Birçok çalışmada diyabet, böbrek rahatsızlıkları ve ailesel yüksek kolestrol seviyesi gibi ateroskleroz oluşumuna eğilimli bireylerde PON aktivitesinin düşük olduğu bulunmuştur (Mackness and Mackness, 2004). Bir çalışmada PON enzim aktivitesinin yetişkinlerde yaşa bağlı olarak arttığı rapor edilmiştir (Seres et al., 2004). PON enzim aktivitesi, yeni doğan bebeklerde ve erken doğmuş bebeklerde yetişkinlerin yaklaşık yarısı civarındadır. Doğduktan sonraki bir yıl içerisinde yetişkinlerin düzeyine ulaşır (Mackness et al., 1998). Kardiyovasküler hastalıklara önayak olan diyet ve yaşam tarzı faktörlerinin PON1 aktivitesini ve/veya konsantrasyonunu etkilediği gözlemlenmiştir (Kudchodkar et al., 2000; Kleemola et al., 2002).Enzim çalışmaları, canlı organizmalar için büyük bir öneme sahiptir. Bazı hastalıklar, özellikle kalıtımsal genetik bozukluklar, bir veya birden fazla enzimin eksikliğinde veya tamamen yokluğunda ortaya çıkmaktadır. Diğer bir grup hastalıklara da enzimin aşırı aktivitesi, neden olabilir. Enzim aktivitelerinin bazı dokularda, kan plazmasinda veya eritrositlerde ölçülmesi birçok hastalığın teşhisi için çok önemlidir. İlaçların çoğu biyolojik etkilerini, enzimlerle etkileşerek ortaya çıkartmaktadırlar (Nelson and Cox, 2005). Tedavi etmesi açısından çeşitli yollarla vücut içerisine aldığımız ilaçların nasıl etki ettiklerini belirlemek ve daha ileri incelemeler için fayda sağlamak adına enzimlerin farklı ilaçlarla olan inhibisyon etkileri rapor edilmiştir (Bayram et al., 2008; Sarikaya et al., 2014; Dilek and Caglar, 2015; Dilek and Polat, 2016; Çiftci et al., 2000). Yaptığımız çalışma kapsamında insan serum PON1 enzimi aktivitesi üzerinde bazı antibiyotiklerin in vitro şartlarda etkileri incelenerek $\mathrm{IC}_{50}$ değerleri ve $\mathrm{K}_{\mathrm{i}}$ sabitleri belirlenmiştir. Çalışmada kullanılan antibiyotiklerin, insan serum PON1 enzimi üzerinde etkilerinin incelenmesiyle ilgili herhangi bir çalışmaya literatürde rastlanılmamıştır. 


\section{Materyal ve Metot}

\section{Kimyasallar}

Sephadex G-200, DEAE-Sephadex A-50, protein analizi reaktifleri ve paraokson Sigma-AldrichCo.'dan temin edildi. Diğer tüm kimyasallar ise Merck'den temin edilmiştir.

\section{İnsan serum PON enziminin saflaştırılması}

PON enzimi ilk olarak amonyum sülfat çöktürmesi ve diyaliz yöntemleri kullanılarak kısmi olarak saflaştırıldı. Daha sonra ilk olarak DEAE-Sephadex A-50 ile yüklenmiş iyon değişim kolonuna tatbik edilerek saflaştırma yapıldı. Aktivite gösteren tüpler birleştirilerek Sephadex G-200 ile yüklenmiş jel filtrasyon kolonuna tatbik edilerek ikinci kez saflaştırma işlemi gerçekleştirildi. Elde edilen insan serum PON1 enzim numunesinin saflığını kontrol etmek için SDS- PAGE (Sodyum dodesil sülfat poliakrilamid jel elektroforezi) yapıldı (Şekil 1).

\section{İnsan Serum Paraoksanoz-I Enziminin Aktivitesinin Ölçümü}

PON1 enziminin paraoksonaz aktivitesi $25^{\circ} \mathrm{C}^{\prime} \mathrm{de} \quad 1 \mathrm{mM} \quad \mathrm{CaCl}_{2}$ içeren $50 \mathrm{mM}$ glisin $/ \mathrm{NaOH}$ tamponu $(\mathrm{pH}=10,5)$ içerisinde paraoksonun (1 $\mathrm{mM})$ substrat olarak kullanılmasıyla belirlendi. Aktivite ölçümü paraokson ile PON1'in reaksiyonu sonucu oluşan paranitrofenol'ün 412 nm'de absorpsiyon vermesi esasına dayanır. Paranitrofenol'ün molar ekstinksiyon katsay1s1 $\left(\varepsilon=18290 \mathrm{M}^{-1} \mathrm{~cm}^{-1} \mathrm{pH}=10,5\right)$ aktivitenin hesaplanması için kullanılır. Paraoksonazın enzim ünitesi, 1 dakikada hidroliz olan paraokson'un mikromol sayısıdır (Renault et al., 2006). PON1 enzimi için aktivite hesabı aşağıdaki gibi yapıldı:

$$
\mathrm{EU} / \mathrm{mL}=\frac{\Delta_{\mathrm{OD}}}{18,290} \times \frac{\mathrm{V}_{\mathrm{T}}}{\mathrm{V}_{\mathrm{E}}} \times 1000
$$

Aktivite hesabında kullanılan yukarıdaki formüldeki simgeler aşağıda ifade edilmiştir;

EU/mL: $1 \mathrm{~mL}$ başına enzim ünitesi

$\Delta_{\mathrm{OD}}$ : Bir dakika içerisindeki absorbans değişimi

18,290: Paranitrofenolün $\mathrm{pH}=10,5$ 'deki molar ekstinksiyon katsayısı

$\mathrm{V}_{\mathrm{T}}$ : Ölçüm yapılan küvetin toplam hacmi

$\mathrm{V}_{\mathrm{E}}$ : Ölçüm yapılan küvete ilave edilen enzimin hacmi

İnsan Serumda Bulunan PON1 Enziminin konsantrasyonlarda ilaç katılarak aktivite Aktivitesi Üzerine Bazı Antibiyotiklerin İn değerleri okundu. Kullanılan antibiyotiklerin Vitro Etkilerinin Belirlenmesi

İnsan serum PON1 enzim aktivitesi üzerine bazı antibiyotiklerin etkilerini belirlemek amacıyla küvet ortamına değişik farklı konsantrasyonlarını oluşturmak için stok çözeltiler seyreltildi. Kullanılan stok çözelti hacmi gereken derişimi sağlamadığı zaman küvete katılan su hacmi azaltılarak stok çözelti hacmi yükseltildi. 
İnhibitör çalışmalarıyla ilgili farklı inhibitör konsantrasyonunda aktivite ölçümü yapılarak ilaç etken maddeleri için \%Aktivite-[I] grafikleri çizildi, eğri denkleminden $\mathrm{IC}_{50}$ değerleri hesaplandı (Şekil 2). Bu maddelerin $\mathrm{K}_{\mathrm{i}}$ değerlerini belirlemek amacıyla insan serumundan saflaştırılan PON1 enzim aktivitesini yarıya düşüren etken madde konsantrasyonu ile bu konsantrasyon değerinden az ve çok olmak şartıyla iki farklı inhibitör konsantrasyonu belirlenir. $\mathrm{Bu}$ değerlerle birlikte daha önceki çalışmalarımızda deneyerek belirlediğimiz uygun beş farklı substrat konsantrasyonu ile enzimin aktivite ölçümleri yapıldı. Her bir inhibitör için Lineweaver-Burk eğrileri çizildi (Şekil 3). Grafik denkleminde yarışmalı inhibisyon için eğime eşit olan $\mathrm{K}_{\mathrm{M}} / \mathrm{V}_{\max }\left(1+[\mathrm{I}] / \mathrm{K}_{\mathrm{i}}\right)$ ifadesinden, yarışmasız ve yarı yarışmalı inhibisyon için $\mathrm{V}_{\max }=\mathrm{VI}$ $\max \left(1+[\mathrm{I}] / \mathrm{K}_{\mathrm{i}}\right)$ formülünden yararlanılarak $\mathrm{K}_{\mathrm{i}}$ değerleri belirlendi. Sonuçlar Tablo 1'de verildi.

\section{Bradford yöntemi ile protein tayini}

Bradford yönteminde boyar madde olarak coomassie brillant blue G-250 kullanılmaktadır. İki formu olan bu boyanın kırmızı formu $465 \mathrm{~nm}$ 'de absorbans verirken, mavi formu $595 \mathrm{~nm}$ 'de absorbans verir. Protein bağlandığı zaman kırmızı form mavi forma dönüşür. Başka bir ifadeyle negatif yüklü bu boya proteinlerin pozitif yüklerine bağlanmaktadır. 595 nm'de maksimum absorbans veren bir kompleks oluşmaktadır. Reaksiyon iki dakika içerisinde gerçekleşir. $\mathrm{Bu}$ yöntemin hassasiyeti 1-100 $\mu \mathrm{g}$ arasındadır (Bradford, 1976).

\section{Bulgular}

$\mathrm{Bu}$ çalışmada da PON1 enzimini saflaştırmak için kaynak olarak insan serumu seçilmiş ve amonyum sülfat çöktürmesi, DEAESephadex A-50 iyon değişim kromatografisi ve Sephadex G-200 jel filtrasyon kromatografisi teknikleri kullanılarak daha önceki çalışmalarımızdaki gibi saflaştırılmıştır. (Dilek and Caglar, 2015; Dilek and Polat, 2016; Dilek et al., 2013; Dilek et al., 2018). Daha sonra siklıkla kullanilan antibiyotiklerin etken maddelerinden olan vankomisin hidroklorür, kolistimetat sodyum, sultamisilin ve sefdinir etken maddelerinin bu enzim üzerindeki inhibisyon etkileri in vitro olarak belirlendi. Çalışmamızda insan serum PON1 enzimi üzerine inhibisyon etkisi gösteren ilaçlar için $\mathrm{K}_{\mathrm{i}}$ sabitlerinin belirlenmesi işleminde Lineweaver-Burk grafikleri kullanılmıştır (Segel, 1986; Telefoncu, 1986). Sonuçların hassas bulunabilmesi için her inhibitörlü çalışma için üç farklı sabit inhibitör konsantrasyonunda $1 / \mathrm{V}$ ile $1 /[\mathrm{S}]$ değerleri elde edilmiştir (Şekil 3). $K_{i}$ sabiti düşük olan inhibitörün enzime ilgisi büyük olduğundan, enzimin katalitik aktivitesi üzerine inhibisyon etkisinin büyük olacağ1 bilinmektedir. Çalışmada kullanılan antibiyotiklerin, insan serum PON1 enzimi üzerinde etkilerinin incelenmesiyle ilgili herhangi bir çalışmaya literatürde rastlanılmamıştır.PON1 enzimi, insan serumundan \%44,6 verimle yaklaşık 320,7 kat saflaştırıldı (Tablo 1). Çalışmamızda kullandığımız etken maddelerin $\mathrm{IC}_{50}$ değerleri sultamisilin için $34.7 \mathrm{mM}$; vankomisin hidroklorür için $3.73 \mathrm{mM}$; sefdinir için $0.59 \mathrm{mM}$ ve kolistimetat sodyum için $13.59 \mu \mathrm{M}$ olarak belirlenmiştir. $\mathrm{K}_{\mathrm{i}}$ sabitleri ise sultamisilin için $38.3 \mathrm{mM}$; vankomisin hidroklorür için $5.08 \mathrm{mM}$; sefdinir için $0.86 \mathrm{mM}$ ve kolistimetat sodyum için 17.01 $\mu \mathrm{M}$ olarak hesaplandı (Tablo 2). PON1 enzimi için sultamisilin ve vankomisin hidroklorür yarışmasız inhibisyon gösterirken, sefdinir yarı yarışmalı inhibisyon, kolistimetat sodyum ise yarışmalı inhibisyon etkisi gösterdi.

\section{Sonuç ve Tartışma}

Genel olarak ilaçların enzimler üzerindeki inhibisyon etkileri IC $_{50}$ (Enzimin aktivitesini $\% 50$ inhibe eden ilaç konsantrasyonu) değeri 
olarak verilmektedir. Kinetik çalışmalar sırasinda enzim aktivitesini inhibe eden antibiyotik, antineoplastik ve kalsiyum kanal blokerlerinin $\mathrm{IC}_{50}$ değerleri belirtilmiştir ( $\mathrm{IC}_{50}$ değeri düşük olan inhibitörün inhibisyon etkisi daha yüksektir). $\mathrm{K}_{\mathrm{i}}$ değerinin hesaplanarak inhibisyon tipleri belirlenebilmektedir. Bunun için en çok kullanılan yöntem Lineweaver-Burk eğrileridir. Lineweaver-Burk eğrileri en az üç farklı sabit inhibitör konsantrasyonunda $1 / \mathrm{V}$ ye karş1 1/[S] grafiği şeklinde çizilir. Kesim noktalarına bakılarak değerlendirmeler yapılabilir (Nelson and Cox, 2005).Yapılan başka çalışmalarda insan serum PON1 enzimi aktivitesi üzerinde başka antibiyotiklerin ve ilaçların in vitro şartlarda etkileri incelenerek $\mathrm{IC}_{50}$ değerleri ve $\mathrm{K}_{\mathrm{i}}$ sabitleri belirlenmiştir. Ekinci ve Beydemir çalışmasında $\mathrm{IC}_{50}$ değerlerini aneljezik ilaçlar olan bilinen lornoksikam, indometasin, tenoksikam, diklofenak sodyum, ketoprofen ve lincomycin için sırasıyla $0.136 ; 0.195$; $0.340 ; 1.639 ; 6.23$ ve $9.638 \mathrm{mM}$; $\mathrm{K}_{\mathrm{i}}$ sabitleri sirasiyla $0.009 ; 0.097 ; 0.306 ; 0.805 ; 13.010$ ve $11.116 \mathrm{mM}$ belirlemiştir (Ekinci and Beydemir, 2009). Türkeş çalışmasında $\mathrm{IC}_{50}$ değerlerini palonosetron hidroklorür, bevasizumab, nifedipin, nitrendipin, isradipin, amlodipin besilat, moksifloksasin hidroklorür, siklofosfamid, levofloksasin hemihidrat, sefepim hidroklorür, gemsitabin hidroklorür için sırasıyla $0.025 ; 0.040 ; 0.121$; $0.130 ; 0.255 ; 0.304 ; 1.839 ; 2.462 ; 3.959$; $21.115 ; 26.610 \mathrm{mM} ; \mathrm{K}_{\mathrm{i}}$ sabitleri sirasiyla $0.033 ; 0.054 ; 0.222 ; 0.151 ; 0.286 ; 0.321$; $2.641 ; 3.419 ; 5.525 ; 35.092 ; 39.598 \mathrm{mM}$ belirlemiştir (Türkeş, 2010). Dilek (2012) çalışmasında $\mathrm{IC}_{50}$ değerlerini netilmisin sülfat, linkomisin hidroklorür, streptomisin sülfat, oksitetrasiklin hidroklorür, penisilin $\mathrm{G}$ potasyum kristalize, klindamisin fosfat, akarboz, pioglitazon hidroklorür, metotreksat için $3.39 ; 13.30 ; 25.39 ; 0.15,32.50 ; 25.40$; 9.82; $0.22 ; 0.18 \mathrm{mM} ; \mathrm{K}_{\mathrm{i}}$ sabitleri sirasiyla $3.73 ; 18.30 ; 56.30 ; 0.20 ; 54.70 ; 35.80 ; 13.10$; 0.32; $0.26 \mathrm{mM}$ belirlemiştir (Dilek, 2012).
Bizim çalışmamızda ki $\mathrm{IC}_{50}$ değerleri sultamisilin için $34.7 \mathrm{mM}$; vankomisin hidroklorür için $3.73 \mathrm{mM}$; sefdinir için 0.59 $\mathrm{mM}$ ve kolistimetat sodyum için $13.59 \mu \mathrm{M}$ olarak belirlenmiştir. $\mathrm{K}_{\mathrm{i}}$ sabitleri ise sultamisilin için $38.3 \mathrm{mM}$; vankomisin hidroklorür için $5.08 \mathrm{mM}$; sefdinir için 0.86 $\mathrm{mM}$ ve kolistimetat sodyum için $17.01 \mu \mathrm{M}$ olarak hesaplandı. Bütün bu çalışmalarda kullanılan antibiyotik ve ilaçlar bizim çalışmamızda kullanılan antibiyotikler gibi PON1 enzimini düşük dozlarda dahi inhibe etmektedir.PON1 enzimi için sultamisilin ve vankomisin hidroklorür yarışmasız inhibisyon gösterirken, sefdinir yarı yarışmalı inhibisyon, kolistimetat sodyum ise yarışmalı inhibisyon etkisi gösterdi. $\mathrm{Bu}$ bilgilerden yola çıkarak kolistimetat sodyumlu ortamda enzimin substrata olan ilgisinin azaldığını $\left(\mathrm{K}_{\mathrm{M}}<\mathrm{K}_{\mathrm{MI}}\right)$, maksimum hizın ise değişmediğini $\left(\mathrm{V}_{\max }=\mathrm{V}_{\max }\right)$ söyleyebiliriz. Sultamisilin ve vankomisin hidroklorür ilave edildiği ortamda ise enzimin substrata olan ilgisinin değişmediğini $\left(\mathrm{K}_{\mathrm{M}}=\mathrm{K}_{\mathrm{MI}}\right)$, maksimum hiz değerinin $\left(\mathrm{V}_{\max }>\mathrm{V}_{\text {maxi }}\right)$ ise azaldığını söyleyebiliriz. Sefdinirli ortamda ise enzimin substrata olan ilgisinin arttığ1 $\left(\mathrm{K}_{\mathrm{M}}>\mathrm{K}_{\mathrm{MI}}\right)$, maksimum hız değerinin $\left(\mathrm{V}_{\max }>\right.$

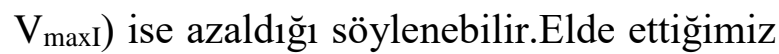
sonuçlara göre uyguladığımız ilaç etken maddelerinin içinde, enzim aktivitesini \%50 oranında azaltması ile en kuvvetli inhibitörün kolistimetat sodyum ( $\mathrm{IC}_{50}$ : $\left.13.59 \mu \mathrm{M}\right)$ olduğunu belirledik. PON1 enzimi pek çok dokuda hayati fonksiyonlara sahip bir enzimdir. PON1 enziminin aktivitesinin azalması bazı durumlarda hayati tehlike doğuran sonuçlara neden olabilir. Özellikle organofosfatlara maruz kalan insanlarda ve vasküler hastalık riski olan insanlarda bu enzimin aktivitesinin değişmemesi gerekmektedir. Bu nedenle bu enzimin hangi maddeler tarafından inhibe edildiğinin araştırılması önemlidir. Çalışmamızdan elde ettiğimiz sonuçlar doğrultusunda, hastalar üzerinde ilaçların göstereceği yan etkilerin nedenlerini araştırırken sağlık sektöründe 
özellikle hekimlere büyük oranda yardımcı olacağı kanaatindeyiz.

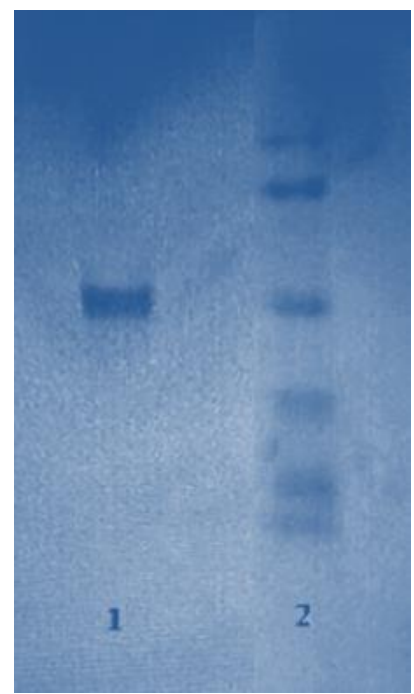

Şekil 1. İnsan serum PON1 enziminin saflaştırma sonucu SDS-PAGE resmi (1.Kanal; Jel filtrasyon kromatografisi sonrası saflaştırılan PON1, 2.Kanal; Standart proteinler; 70-18 kDa)
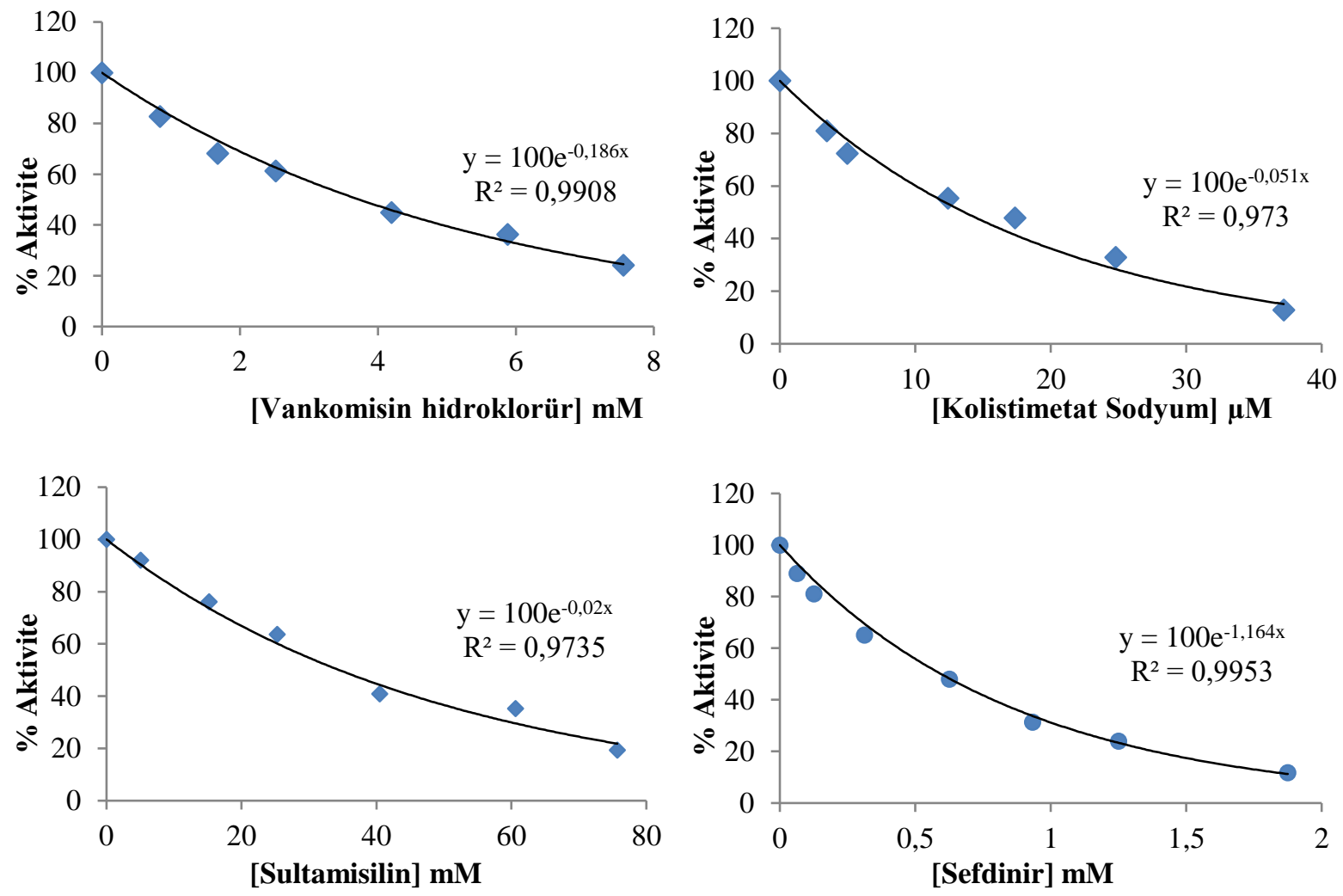

Şekil 2. Vankomisin hidroklorür, kolistimetat sodyum, sultamisilin ve sefdinir etken maddelerinin İnsan Serum PON1 Enzimine karşı \%Aktivite-[I] grafikleri 


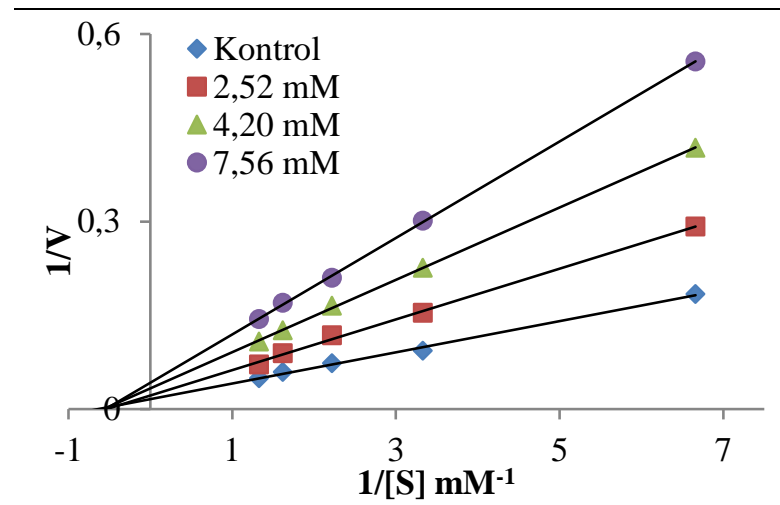

1

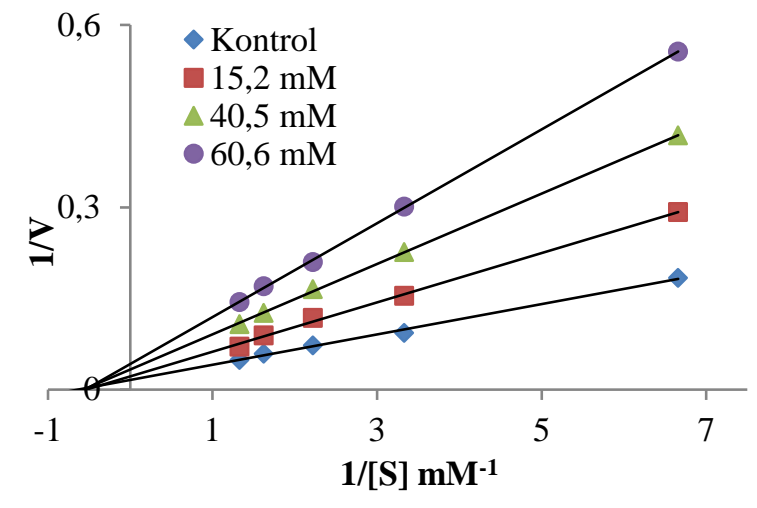

3

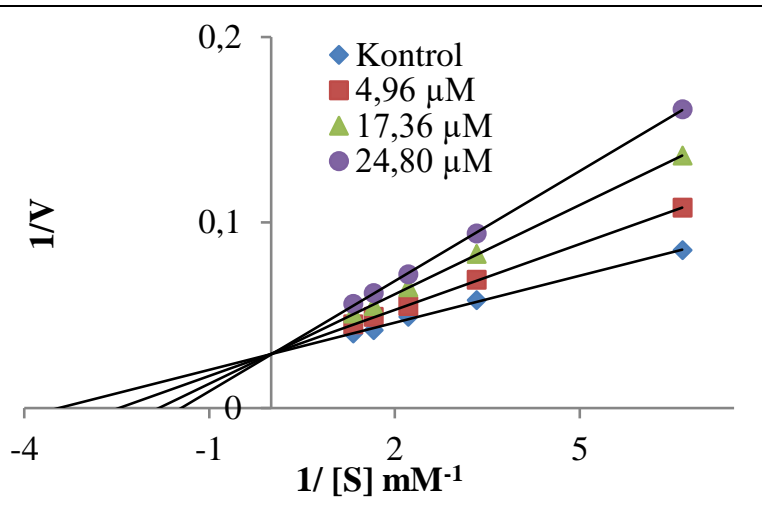

2

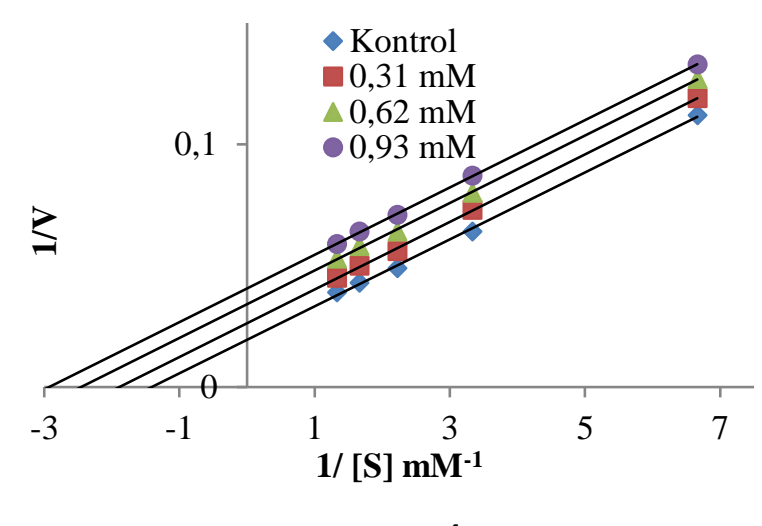

4

Şekil 3. Vankomisin hidroklorür (1), kolistimetat sodyum (2), sultamisilin (3) ve sefdinir (4) etken maddelerinin PON1 enzimine karşı Lineweaver-Burk grafikleri

Tablo 1. İnsan serum PON1 enzimi için saflaştırma basamakları

\begin{tabular}{lcccccc}
\hline & $\begin{array}{c}\text { Aktivite } \\
(\mathbf{E U / m l})\end{array}$ & $\begin{array}{c}\text { Protein } \\
(\mathbf{m g} / \mathbf{m l})\end{array}$ & $\begin{array}{c}\text { Toplam } \\
\text { Aktivite } \\
(\mathbf{E U )})\end{array}$ & $\begin{array}{c}\text { Spesifik Aktivite } \\
(\mathbf{E U / m g ~ p r o t e i n )})\end{array}$ & $\begin{array}{c}\text { Verim } \\
(\mathbf{\%})\end{array}$ & $\begin{array}{c}\text { Saflaştırma } \\
\text { Katsayıs }\end{array}$ \\
\hline $\begin{array}{l}\text { Triton X-100 Uygulanmış } \\
\text { Serum }\end{array}$ & 90 & 7,7 & 2336 & 11,68 & 100 & - \\
$\begin{array}{l}\text { A.S }(\% 60-80) \text { ve } \\
\text { Diyaliz }\end{array}$ & 125 & 5,1 & 1672 & 24,5 & 71,6 & 2,09 \\
$\begin{array}{l}\text { DEAE Sephadex A50 İyon } \\
\text { Değişim }\end{array}$ & 168 & 0,079 & 1245 & 2126,6 & 53,3 & 182,1 \\
$\begin{array}{l}\text { Sepdadex G-200 Jel } \\
\text { Filtrasyon Kromatografisi }\end{array}$ & 221 & 0,059 & 1043 & 3745,8 & 44,6 & 320,7 \\
\hline
\end{tabular}

Tablo 2. Vankomisin hidroklorür, kolistimetat sodyum, sultamisilin ve sefdinir ilaç etken maddelerinin PON1 enzimine karşı $\mathrm{IC}_{50}, \mathrm{~K}_{\mathrm{i}}$ değerleri ve inhibisyon tipleri.

\begin{tabular}{lccc}
\hline İnhibitör & $\begin{array}{c}\mathbf{I C}_{\mathbf{5 0}} \text { değeri } \\
(\mathbf{m M})\end{array}$ & $\begin{array}{c}\mathbf{K}_{\mathbf{i}} \mathbf{d e g ̆ e r i} \\
(\mathbf{m M})\end{array}$ & İnhibisyon Tipi \\
\hline Vankomisin hidroklorür & 3.73 & 5.08 & Yarışmasız inhib. \\
Kolistimetat sodyum & 0.014 & 0.017 & Yarışmalı inhib. \\
Sultamisilin & 34.7 & 38.3 & Yarışmasıs inhib. \\
Sefdinir & 0.59 & 0.86 & Yarı yarışmalı inhib. \\
\hline
\end{tabular}




\section{Kaynaklar}

Aviram, M., Rosenblat, M., Bisgaier, C.L., Newton, R.S., Primo-Parmo, S.L., La Du, B.N. 1998. Paraoxonase inhibits high-density lipoprotein oxidation and preserves its functions. A possible peroxidative role for paraoxonase. The Journal of clinical investigation. 101(8), 1581-1590.

Bayram, E., Şentürk, M., Küfrevioğlu, Ö.İ., Supuran, C.S. 2008. Invitro inhibition of salicylic acid derivatives on human cytosolic carbonic anhydrase isozymes I and II. Bioorganic and Medicinal Chemistry. 16: 9101-9105.

Blatter, M.C., James, R.W., Messmer, S., Barja, F. Pometta, D. 1993. Identification of a distinct human high-density lipoprotein subspecies defined by a lipoprotein-associated protein, K-45: Identity of K-45 with paraoxonase. European journal of biochemistry. 211(3), 871-879.

Bradford, M.M. 1976. A rapid and sensitive method for the quantitation of microgram quantities of protein utilizing the principle of protein-dye binding. Analytical biochemistry. 72(1-2), 248-254.

Canales, A. Sanchez-Muniz, F.J. 2003. Paraoxonase, something more than an enzyme? Medicina clinica. 121(14), 537-548.

Ciftçi, M., Küfrevioglu, O.I., Gündogdu M., Ozmen, I. 2000. Effects of some antibiotics on enzymeactivity of glucose-6-phosphate dehydrogenase from human erythrocytes. Pharmacol Res. 41:109-13.

Dilek, E. 2012. İnsan Serumundan Paraoksonaz-1 ve İnsan Trombositlerinden Siklooksigenaz-1 Enziminin Saflaştırılması, Bazı İlaçların $\mathrm{Bu}$ Enzimlerin Aktiviteleri Üzerine Etkilerinin İncelenmesi. Doktora Tezi, Atatürk Üniversitesi Fen Bilimleri Enstitüsü, Erzurum.
Dilek, E., Caglar, S. 2015. Effects of mono and dinuclear copper (II) complexes derived from non-steroidal antiinflammatory drug naproxen on human serum paraoxanase1 (PON1) activity. Intl. J. Pharm. Chem. 5(6), 189-195.

Dilek, E., Caglar, S., Erdogan, K., Caglar, B., Sahin, O. 2018. Synthesis and characterization of four novel palladium (II) and platinum (II) complexes with 1-(2-aminoethyl) pyrrolidine, diclofenac and mefenamic acid: In vitro effect of these complexes on human serum paraoxanase1 activity. Journal of biochemical and molecular toxicology. 32(4), e22043.

Dilek, E., Polat, M.F. 2016. In Vitro Inhibition Of Three Different Drugs Used In Rheumatoid Arthritis Treatment On Human Serum Paraoxanase 1 Enzyme Activity. Protein andPeptideLetters. 23, 3-8

Dilek, E.B., Küfrevioğlu, Ö.İ., Beydemir, Ş. 2013. Impacts of some antibiotics on human serum paraoxonase 1 activity. Journal of enzyme inhibition and medicinal chemistry. 28(4), 758764.

Durrington, P.N., Mackness, B., Mackness, M.J. 2001. Paraoxonase and atherosclerosis. Arteriosclerosis, thrombosis, and vascular biology, 21(4), 473-480.

Ekinci, D., Beydemir, S. 2009. Effect of some analgesic on purified paraoxonase-1 from human serum", Journal of Enzyme Inhibition and Medicinal Chemistry. 24(4), 10341039.

Gan, K.N., Smolen, A., Eckerson, H.W., La Du, B.N. 1991. Purification of human serum paraoxonase / arylesterase. Evidence for one esterase catalyzing both activities. Drug Metabolism and Disposition. 19(1), 100-106.

Kleemola, P., Freese, R., Jauhiainen, M., Pahlman, R., Alfthan, G., Mutanen, 
M. 2002. Dietary determinants of serum paraoxonase activity in healthy humans. Atherosclerosis. 160(2), 425432.

Kudchodkar, B.J., Lacko, A.G., Dory, L., Fungwe, T.V. 2000. Dietary fat modulates serum paraoxonase 1 activity in rats. The Journal of nutrition. 130(10), 2427-2433.

Lee, J., Prohaska, J.R. Thiele, D.J. 2001. Essential role for mammalian copper transporter Ctr1 in copper homeostasis and embryonic development. Proceedings of the National Academy of Sciences. 98(12), 6842-6847.

Mackness, B., Durrington, P.N., Mackness, M.I. 1998. Human serum paraoxonase. General Pharmacology: The Vascular System. 31(3), 329-336.

Mackness, M., Mackness, B. 2004. Paraoxonase 1 and atherosclerosis: is the gene or the protein more important? Free Radical Biology and Medicine. 37(9), 1317-1323.

Nelson, D.L., Cox, M.M. 2005. Lehninger principles of biochemistry. WH Freeman \& Co, New York. 4, 1100.

Ng, C.J., Shih, D.M., Hama, S.Y., Villa, N., Navab, M., Reddy, S.T. 2005. The paraoxonase gene family and atherosclerosis, Free Radical Biology and Medicine. 38(2), 153-163.

Renault, F., Chabrière, E., Andrieu, J.P., Dublet, B., Masson, P. Rochu, D. 2006. Tandem purification of two HDL-associated partner proteins in human plasma, paraoxonase (PON1) and phosphate binding protein (HPBP) using hydroxyapatite chromatography. Journal of Chromatography B. 836(1-2), 15-21.

Sarikaya, S.B., Sisecioglu, M., Cankaya, M., Gulcin, I., Ozdemir, H. 2014. Inhibition profile of a series of phenolicacids on bovine lactoperoxidase enzyme. J. Enzyme Inhib. Med. Chem. 8: 1-5.

Segel, I.H. 1986. Enzyme Kinetics, John Wiley and Sons, 1975; New York.
Seres, I., Paragh, G., Deschene, E., Fulop, Jr T., Khali, A. 2004. Study of factors influencing the decreased HDL associated PON1 activity with aging. Experimental gerontology. 39(1), 5966.

Telefoncu, A. 1986. Temel ve Uygulamal1 Enzimoloji. Ege üniversitesi, Fen Edebiyat Fakültesi Yayını (Der). 59 s, İzmir.

Türkeş, C. 2010. İnsan Serumundan Paraoksonaz-1 Enziminin Saflaştırılması ve Bazı İlaçların Enzim Aktivitesi Üzerine Etkilerinin İncelenmesi. Yüksek Lisans Tezi, Atatürk Üniversitesi Fen Bilimleri Enstitüsü. Erzurum. 